\title{
KURIOS
}

(Jurnal Teologi dan Pendidikan Agama Kristen)

Vol. 3, No. 1, Oktober 2015 (12-21)

ISSN 2406-8306 (print)

http://www.sttpb.ac.id/e-journal/index.php/kurios

\section{Nubuatan Tentang Mesias dalam Perjanjian Lama Berdasarkan Kitab Sejarah}

\author{
Hery Sihaloho \\ Sekolah Tinggi Teologi Pelita Bangsa Jakarta
}

\section{Pendahuluan}

Di dalam kitab PL terdapat nubuatan akan datang Mesias. Secara keseluruhan terkandung 300 nubuatan yang berkenaan dengan Mesias. Semuanya itu terpenuhi didalam Yesus Kristus, dan memenuhi kredibilitasnya sebagai Mesias (McDowell, 2002:232). Nubuatnubuat Mesianis itu menjelaskan tentang silsilah, kelahiran, kehidupan, kematian dan kebangkitan. Bahkan ada juga nabi yang menubuatkan tempat atau kota dimana Mesias dilahirkan.

Dalam bukunya "Yesus Kristus Tuhan Kita", Walvoord mengatakan bahwa nubuatan mengenai Mesias sebelum Yesus lahir sangat penting, karena tidak ada yang lain di dunia ini yang pernah diramalkan secara demikian, juga karena tidak ada orang lain yang diberitahu sebelumnya memiliki kuasa dan sifat-sifat Allah seperti kepada Kristus. Nubuat itu sendiri sudah merupakan sebuah mujizat dan memberikan kesaksian mengenai seorang yang liar biasa (Walvoord, :70).

Dalam makalah ini akan diuraikan secara bertunitᄀturut mengenai nubuatan akan Mesias dalam PL. Adapun batasan yang ingin diteliti adalah berdasarkan penelitian kitabkitab sejarah. Sebelum masuk kepada kitab sejarah, penulis mencoba memberikan beberapa penjelasan mengenai nubuat yang terjadi di Israel dan Timur Dekat Kuno, dalam hal ini penulis dapat menjelaskan perkembangan nubuat tentang Mesias dalam periode sejarah PL. Lalu pokok selanjutnya ialah menjelaskan tentang orang yang menubuatkan berita tersebut yaitu nabi sebagai juru bicara Tuhan pada periode permulaan Israel. Di tambah lagi dengan waktu dan tempat ketika Firman Allah disampaikan. Dan untuk mengetahui cara berkomunikasi dengan nubuatan maka penulis akan menjelaskan bentuk penyampaian Firman Allah dalam konteks nubuatan. Pada intinya akan membawa kepada tujuan penulisan yaitu nubuatan tentang Mesias dalam PL., khususnya dalam ungkapan kitab $\neg$ kitab sejarah. 


\section{Pengertian Nubuat}

Walvoord dengan mengutip tulisan William $\mathrm{H}$ Thomson menjelaskan bahwa nubuat yang sejati adalah suatu mujizat, karena sifatnya yang begitu berbeda dengan ramalan manusia belaka. Menurutnya nubuat tidak memiliki hubungan dengan pengalaman (seperti kata manusia), atau ditentukan oleh pengalaman, karena nubuatan itu dasarnya adalah kemampuan mengetahui terlebih dahulu, dimana tak seorangpun mempunyai kemampuan ini tanpa suatu pertolongan (Walvoord, :70). Pengertian lain dari Josh Mc Dowell ialah bahwa nubuat merupakan suatu tanda dari kuasa dan kemuliaan Allah dan menunjukkan sifat ajaib perkataanNya. Itu bukan hanya suatu pertunjukkan dari kuasa Allah, tetapi juga merupakan jawaban bagi doa dan kebutuhan manusia. Karena Allah mengungkapkan masa depan suatu pekerjaan yang tidak dapat dilakukan oleh seorang manusia pun (2002:412). Dengan demikian nubuatan merupakan pernyataan Ilahi yang terkandung makna religius sebagai penuntun kepada hidup yang sejahtera.

\section{Pengertian Mesias}

Pada umumnya pengertian Mesias diambil dari bahasa Aram dan Ibrani yaitu "Mashach" yang berarti "yang diurapi". Menurut Siahaan, pada awalnya menunjuk kepada raja yang sedang berkuasa pada kerajaan Israel raya, terutama yang berasal dari dinasti Daud. Dalam PL istilah tersebut kadang-kadang digunakan untuk raja Israel yang sedang menjabat (1990:3). Tetapi lambat laun istilah Mesias digunakan pada Raja keselamatan yang akan datang, yaitu sebagai pengharapan bangsa Israel (1990:4). Berdasarkan pengertian di atas maka para ahli menyepakati bahwa pengharapan akan Mesias ditunjukkan kepada keturunan Raja Daud digenapi di dalam diri Yesus Kristus.

\section{Nubuat di Israel dan Timur Dekat Kuno}

Harry Mowvley seorang pengajar di Bristol Baptist Collage, dalam bukunya "Penuntun ke dalam Nubuat Perjanjian Lama" menyatakan bahwa di Timur Dekat Kuno juga terdapat nubuatan atau rujukan yang hampir menyerupai nubuatan yang dimiliki oleh Israel. Oracle atau ramalan-ramalan dalam tradisi di luar Israel memiliki gaya yang berbeda, didalamnya menunjukkan kepada Dewa yang menjadi penguasa pada waktu itu. Tetapi dewa mereka tidak memberikan pesan kepada "Baru" teks "Mari" seperti ahli nujum atau sihir (para pelihat), justru pelihat itu yang berusaha untuk mempengaruhinya melalui doa yaitu dengan mendekati diri mereka sendiri untuk melakukan apa yang mereka inginkan (2000:8). Para nabi perjanjian lama umumnya dianggap sebagai orang-orang yang menjalankan fungsi untuk 
menceritakan apa yang terjadi. Nubuat-nubuat di Israel yang diucapkan oleh para Nabi kadangkala melihat jauh ke depan dan iman mereka kepada Allah memampukan mereka untuk mengungkapkan harapan-harapan yang sama sekali belum digenapi. Mereka (nabinabi) sekedar mengungkapkan implikasi-implikasi pemahaman atau pengertian mereka tentang Allah untuk masa depan.

Sedangkan Nubuat dalam pandangan Timur Dekat Kuno lebih menyerupai kepada Nabi-Nabi Perjanjian Lama tetapi terkesan Fenomenal dan Spekulatif. Menurut para ahli pada tahun 1933, M. Andre Parrot seorang Arkeolog Perancis menggali sekitar 20.000 kepingan tanah liat di dalam bangunan-bangunan istana Raja Zimri-Lin. Diantaranya ada sejumlah kepingan yang memuat rujukan-rujukan pada orang-orang yang mirip dengan Nabi-Nabi Israel. Menurut ahli sebuah kepingan menceritakan tentang seorang laki-laki bernama Malik, yang bermimpi menerima sebuah pesn dari Dewa Dagon. Ia harus mengumumkan pesan ini kepada Gubernur yang akan meneruskannya kepada Raja Zimri-Lin. Pesan (intbita0 tersebut meminta Zimri-Lin taat kepada Dagon yang pada saatnya nanti akan menghadiahkan kemenangan-kemenangan atas "orang-orang dari selatan".

\section{Nabi Sebagai Juru bicara Tuhan}

Pada umumnya ada tiga kata Ibrani yang dipakai untuk Nabi, Nay", Ro'eh, Khozeh. Yang pertama senantiasa diterjemahkan "Nabi", yang kedua dalam bentuk aktif berarti "melihat", atau "pelihat" (Ensiklopedi Alkitab Masa Kini : 169). Tetapi bisa juga menunjuk kepada melihat sebuah penglihatan, sama seperti halnya melihat secara Harfiah dengan mata, hal ini terdapat dalam 2 Samuel 24:11, yaitu mengenai nabi Gad (Mowvley, 2000:14).

Sebagai juru bicara Tuhan, nabi itti berfungsi untuk mempertahankan dan memperteguh umat Allah dalam kepercayaan sejati kepada Tuhan yang mengikat perjanjiannya dengan umat pilihannya. Pada waktu bangsa Israel menyimpang dari perjanjian, menjadi tidak setia, maka nabi tampil sebagai juru bicara untuk menegur dan mengecam umat beserta pemimpinnya. Atas nama Tuhan para nabi mengancam hukuman berat kepada umat yang berdosa. Sebaliknya, ketika umat tertimpa kemalangan menjadi putts asa dan hampir saja kehilangan kepercayaan dan pengharapannya. Nabi-nabi tersebut mengingatkan bahwa Tuhan tetap setia, mengampuni dosa umat yang bertobat dan menyelamatkan dari kemalangan dan kehancuran. Di samping itu juga, nabi kadang-kadang berbicara tentang masa depan, melayangkan pandangannya ke zaman akhir (eskatologis).

Dalam konteks nubuatan Mesias, nabi pun mengungkapkan tentang seorang raja keselamatan yang akan datang sebagai pengharapan bangsa Israel. Groenen mengatakan 
bahwa para nabi yakin bahwa Tuhan tidak pernah akan meninggalkan atau menolak umat yang pernah dipilihnya, Tuhan pasti akan melaksanakan rencana penyelamatanNya (1988:212).

\section{Waktu dan Tempat Firman Allah Disampaikan}

Unger's Bible Dictionary menentukan waktu pelayanan para nabi atau penulisan kitabkitab sebagai berikut :

Amos, Abad ke-8 SM (760-755 SM).

Daniel, 605-538 SM.

Yehezkiel, 592-570 SM

Hose, 748-690 SM

Yesaya783-738 SM ke-1; 735-719 SM ke-2; 719-704 SM ke-3

Yeremia, 626-586 SM

Yoel, sebelum $300 \mathrm{SM}$

Imamat (Musa), 1520-1400 SM

Mika, di atas 738-690 SM

Nahum, 661-612 SM

Obaja, sebelum 300 SM

Zefanya, di atas 640-621 SM

Penanggalan (waktu) tersebut dalam beberapa kasus masih belum pasti, karena Unger memakai isi dari tulisan para nabi itu sendiri sebagai dasar pertimbangan untuk menentukan penanggalan dari berbagai buku tersebut. Tetapi kadang-kadang nabi itu tidak menunjukkan dengan jelas waktu yang tepat dari tulisannya. Dari daftar di atas hanya kitab Yoel dan Obaja sama sekali tidak memberikan informasi konkret dari penulisannya untuk menentukan suatu tulisan yang pasti.

Mengenai tempat dimana nabi-nabi menyampaikan Firman Allah dalam nubuatan adalah berada di Asyur dan Babel, termasuk juga bangsa-bangsa yang ada di sekitar Israel. Sebelumnya mereka bemubuat di Yehuda dan Israel (kerajaan Utara dan Selatan). Tetapi sebelum bangsa Israel masuk ke dalam pembuangan ada juga nabi yang bemubuat seperti Yeremia. Dan di tengah-tengah pembuangan seperti Daniel dan Yehezkiel, termasuk Habakuk. Pada masa pasca pembuangan terdapat nabi Hagai dan Zakaria. Jadi berdasarkan waktu dan tempat itulah nubuatan mesias disampaikan oleh para nabi, baik di Israel maupun di Yehuda, dan juga pada masa dimana raja-raja memerintah. 


\section{Bentuk Penyampaian Firman Allah}

Dalam nubuatan Firman Allah diungkapkan dalam bentuk kata-kata yang diucapkan. Masing-masing nabi mewarnai ucapannya dengan ciri pribadi dan pengalamannya sendiri. Allah memakai nabi-nabiNya sebagai mulutNya, kata $\neg$ kata yang mereka ucapkan adalah Firman Allah (Dabar). Tetapi nabi juga dapat mengemukakan Firman yang dibawanya dalam bentuk perumpamaan atau alegori, seperti yang terdapat dalam Yeremia 5:1-7, 2 Samuel 12:17 (Ensiklopedi Masa Kini, 1995:166).

Ciri lainnya ialah bahasa nubuatan seringkali terang ᄀterangan dan tanpa kekangan, dengan memakai banyak metafora dan berbagai jenis lainnya. Lebih jauh lagi lainnya, penyampaian dalam bentuk puisi tadi mengharapkan adanya reaksi pribadi dari pembaca ataupun pendengar, artinya suatu tanggapan yang bukan hanya dalam emosi melainkan juga dalam tindakan (Mowvley, 2000:52).

Mowvley juga mengatakan bahwa tiap-tiap nabi memakai gaya dan perbedaan dalam menyampaikan nubuatan. Misalnya nabi Yesaya dengan nyanyian-nyanyian (Yes. 5:1 7). Amos dengan gaya kenabiannya is menggunakan bentuk ibadah (Amos 4:4), Amos berada di Betel memanggil umatnya untuk beribadah seperti yang biasa dilakukan oleh imam dan para anggotanya. Kadangkala Yesaya juga memakai bahasa atau gaya dari rang pengadilan, nubuatnya dikemas dalam bentuk perdebatan hukum (Yes. 3:13), begitu juga nabi Hosea dalam ucapannya di 12:2 (2000:54).

Dengan demikian ketika nubuatan mesias disampaikan dalam bentuk nyanyian atau ucapan simbolis (seringkali dalam Yesaya dan Mazmur) maka hal itu merupakan sebuah alat yang penting untuk dapat memahami pesan nabi.

\section{Pokok-pokok Pemberitaan Nabi}

Pada umumnya didalam Alkitab khusunya PL, inti pemberitaan nabi-nabi tertuju kepada kekudusan Allah dan kekudusanumat, begitu jugakebenaran dan keadilan ditegakkan ditengah-tengah dosa yang membuat hati Allah kecewa. Setiap kali bernubuat nabi tidak pernah berhenti menyampaikan kebenaran dan menegur dosa-dosa bangsa Israel, dan tidak segan-segan nabi mengucapkan penghakiman, murka dan penghukuman yang akan Allah laksanakan bila tidak menaati ketetapan Allah. Lain dari itu, Allah adalah kasih, dalam hal ini nabi pun menubuatkan tentang pengampunan Allah dan kebaikan Allah untuk membuat bangsanya kembali kepada Yahweh sebagai satu-satunya Tuhan.

Seluruh pokok-pokok tersebut tidak berhenti sampai batas nabi-nabi menubuatkan untuk mereka kembali dari pembuangan. Lebih dari itu nabi-nabi mendeklarasikan 
pengharapan masa depan khususnya pengharapan mesias yang jauh sebelumnya pernah diungkapkan oleh nabi ditengah pemerintahan raja-raja Israel, pengharapan mesias itu akan diwujudkan di dalam Kristus Yesus yang akan datang ice bumi. Dengan demikian nubuatan demi nubuatan tentu memiliki makna bagi perkembangan sejarah Israel umumnya dan kekristenan khususnya.

\section{Ciri Utama dan Nubuatan Tentang Mesias}

John F. Walvoord membagi dua bagian utama dari nubuatan tentang Mesias. Pertama, nubuatan tentang mesias dari garis umum merupakan nubuatan yang diungkapkan dalam bahasa yang hanya dapat digenapkan oleh mesias itu sendiri. Contohnya 1 Samuel 2:35. Kedua, Nubuatan tentang Mesias secara pribadi. Hal ini dapat ditemui dalam istilah $\neg$ istilah khusus misalnya Yes. 7:14 yang menggunakan istilah "Immanuel" ( :72).

Begitu juga yang terdapat didalam kitab Amos, khususnya Amos 8:3,9,13, menurut Barnabas Ludji, dalam nubuatan ini menyampaikan Tuhan mengumumkan bangunan kembali dinasti atau kerajaan Daud. Istilah yang dipakai ialah "Pondok Daud", Tuhan berkata "AKu akan mendirikan kembali Pondok Daud yang telah roboh". Ludji menyatakan bahwa kata "mendirikan" merefleksikan pengaruh perjanjian Allah dengan Daud (II Samuel 7:5-13,27). Perjanjian itu sangat menekankan pengharapan masa depan yang mengarah kepada sang Mesias (1999:5). Dan masih banyak yang menjadi istilah atau ciri nubuatan tentang Mesias. Seluruh bagian yang ada di dalam PL, khususnya memakai ungkapan pribadi maupun umum, dan juga penggunaan silsiah yang mengacu kepada Mesias asalkan dengan penafsiran yang benar dan beralasan maka dapat dikatakan sebagai penyingkapan yang tersembunyi dari sisi Ilahi.

\section{Silsilah Mesianis}

Jauh sebelumnya garis keturunan mengenai Mesias sudah dibicarakan dimulai dari Adam dan Hawa, yaitu ketika mereka jatuh kedalam dosa. Juruslamat yang akan datang itu adalah keturunan perempuan (Kej. 3:15), keturunan Abraham (Kej. 12:1-3), sampai kepada Daud (II Sam. 7:12-13).

Dalam kisah Rut dan Boas, Walvoord menjelaskan bahwa pasangan tersebut merupakan bagian dari rencana Ilahi yang berdaulat didalam garis keturunan mesias, lalu garis keturunan Raja Daud dihubungkan dengan Yehuda ( :75).

Dalam PB, silsilah mengenai mesias lebih diurutkan, misalnya Matius menetapkan bahwa Yesus adalah keturunan Daud yang sah dengan menghubungkan garis keturunan Yusuf yang berasal dari keluarga Daud. Begitu juga dalam Lukas, dengan demikian para penulis 
kitab Injil menegaskan bahwa Yesus berhak menjadi Mesias baik secara hukum maupun biologis ? (Mat. 1:1-17, Mrk. 3:23-38).

\section{Pembahasan}

Dalam PL khususnya kitab-kitab sejarah tidak sebanyak kitab nabi-nbi mengenai nubuatan mesianis, mulai dari Yosua, Hakim-Hakim, Rut sampai kepada Ester hanya beberapa saja yang menunjukkan nubuatan mesianis. Tetapi secara umumnya, tiap-tiap kitab memiliki kehadiran Kristus dari segi tipelogi dan kesamaan dari tokoh-tokoh yang ada didalam kitab tersebut. H. Senduk dalam bukunya "Kristus dalam PL" banyak menuliskan atau mengkaitkan pribadi Kristus dalam tiap-tiap kitab, dengan mengadakan studi perbandingan baik dari sisi kehidupan maupun kepemimpinannya. Berbeda dengan tulisan Kenneth E. Trent dalam "Types of Christ in The Old Testament", Ia mengatakan bahwa sebagian besar di dalam PL terdapat berbagai tipe dan mengenai Kristus. Berbagai macam nama dan peristiwa memiliki kaitannya dalam buku tersebut, trent dengan pendekatannya dengan teologis menjelaskan secara sederhana dan memungkinkan.

Dengan demikian apabila dilihat secara keseluruhan maka hanya kitab I dan II Samuel saja yang banyak menyinggung dan berhubungan dengan Mesias. Nubuat tersebut bila diselidiki memiliki makna yang kuat tentang pribadi Kristus, sedangkan untuk kitab Rut, tidak terdapat nubuatan tentang Mesias disana melainkan sejarah yang menceritakan garis keturunan Yesus Kristus sebagai Mesias yang terdapat dalam Rut 4:18-22. Dalam ayat 17 nama Obed disebutkan sebagai ayah Isai, dan Daud merupakan anak Isai. Dengan demikian sejarah membuktikan bahwa rencana ilahi tersebut berjalan dalam garis keturunan atau silsilah.

Beberapa ahli PL mengakui bahwa nubuatan tentang mesias mulai $\mathrm{j}$ elas dan nyata ketika Nabi Natan mengungkapkan misteri Ilahi yang tertuju kepada Kristus. Tetapi sebelumnya seorang abdi Allah bernubuat tentang kedatangan Mesias sebagai imam dalam I Sam. 2:35. Menurut Walvoord keimaman Kristus diramalkan dalam seluruh system Imamat yang diberikan berdasarkan Wahyu, sistem tersebut menurut aturan Lewi dan kepada keluarga sebagai Imam. Itu sebabnya nubuat yang terdapat dalam I Sam. 2:35 dapat digenapkan seluruhnya hanya oleh Kristus ( :79).

Hal yang penting dalam kitab-kitab sejarah ialah nu $\neg$ buatan yang terdapat dalam 2 Sam. 7:12-16, dalam nubuatan tersebut dijelaskan bahwa keturunan Daud akan ditetapkan dalam kedatangan Mesias yang tahtanya dan kerajaannya akan sampai selamanya. Josh Mc Dowell menyetujui pernyataan Driver bahwa 2 Sam. 7:11b menerangkan janji ini tidak 
berlaku bagi Daud sendiri, tetapi bagi keturunannya, dan pernyataan bahwa bukan Daud yang akan mendirikan lewat keturunan Daud yang akan mendirikan rumah bagi yahweh, tetapi yahweh yang akan mendirikan lewat keturunan bagi Daud, dengan demikian tahtanya tidak akan berakhir sampai kepada kristus sebagai Mesias (2002:238). Para ahli dari fundamentalis maupun konservatif mengakui bahwa penggenapan nubuat ini berhubungan dengan Kristus saja. Hal ini dapat dibuktikan oleh karena dalam teks tersebut memiliki kaitannya dengan Mzm. 89:4-5,21,28030, Mzm 132:11, Yer. 23:5; 33:14-15. Walter A Elwell menyatakan bahwa nubuatan tersebut terpenuhi dalam Mat. 2:19, Mat. 22:42, Yoh. 7:42, KPR 13:22-23 dan Roma 1:3 (2001:170).

Walter C. Kaiser, Jr. memberikan beberapa tanggapan eksegesis terhadap 2 Samuel 7 dengan duplikatnya di dalam I Tawarikh 17, di dalam pengamatannya is menjelaskan makna "keturunan,"rumah" dan "kerajaan" (2000:195). "Keturunan," (house) Daud harus dibangkitkan dahulu oleh Yahwe sebelum semua bait suci dapat didirikan. Dalam hal ini juga Allah berjanji untuk memberikan "keturunan" (bayit) kepada Daud. Bayit juga berarti tempat tinggal, termasuk keluarga yakni orang tua, anak-anak, dan sanak keluarga. Dengan demikian di dalam 2 Samuel 7 arti "dinasti" paling tepat, terutama karena ungkapan "keluarga dan kerajaanmu akan kokoh untuk selamanya", ini menunjukkan bahwa "dinasti" Daud akan memerintah selamanya. Dan pemberian ini juga akan berlangsung terus sampai masa yang akan datang.

Kaiser juga menuliskan bahwa didalam 2 Samuel 7, delapan kali Yahwe berjanji akan memberikan Daud keturunan (ayat 11, 13, 16, 19, 25, 26,27, 29), belum termasuk hal-hal dengan ide serupa yang menggunakan istilah lain (2000:196). Dalam hal "keturunan" (seed) terdapat satu kali saja yaitu di 2 Samuel 7:12. "seed" disini berarti sekaligus menunjukkan kepada satu oknum yang mewakili seluruh kelompok dan yang merupakan jaminan satu garis keturunan yang akan datang. Jadi "keturunan" Daud akan membangun bait suci yang dimaksud (2 Sam. 7:13), artinya adalah Salomo, tetapi pada waktu yang sama rumah yang abadi itu tidak akan pernah kekurangan keturunan untuk menduduki tahta Daud, (2000:197).

Pokok lain yang ditekankan ialah "kerajaan", Kaiser menyatakan bahwa selama zaman pra-bapak leluhur dan kitab Keluaran bahwa Israel akan mempunyai Raja-raja" (kej. 17:6; 35:11), termasuk sebuah "kerajaan" (Kel. 19:6, Bil. 24:7) dan "kekuasaan" (Bil. 24:19). Sekarang kerajaan tersebut telah diberikan kepada Daud dan keluarganya menurut 2 Sam. 7:23ᄀ24, 26, 27 (2000:197). Dengan demikian, karena Tuhan yang mendirikannya, maka kerajaan itu tidak dapat ditarik kembali dan bersifat abadi. 
Pemahaman Daud mengenai perjanjian itu ialah bahwa Daud menyatakan pengertiannya mengenai perjanjian tersebut, "Engkau telah mengokohkan bagi-Mu z1171Cli $\neg \mathrm{Mu}$ Israel menjadi umat-Muff untuk selama-lamanya, dan Engkau, ya TUHAN, menjadi Allah mereka." (2 Samuel 7:24). Begitu juga ayat-ayat seterusnya, Daud memahami janji itu akan berlaku selamanya (ayat 26-29). Dan dalam ayat 24 Daud menganggap Israel dan keturunannya sendiri akan diteruskan sampai selama-lamanya. John F. Walvoord dalam bukunya mengatakan bahwa pemahaman Daud tentang janji tersebut mengacu kepada bangsa Israel, bukan kepada bangsa lain, secara khusus mengacu kepada keturunannya secara jasmani, menurutnya, dalam pikiran Daud tidak ada untuk mengacaukan tahtanya dan keturunan fisiknya sendiri dengan tahta Allah di surga dan umat Allah secara keseluruhan (1996:11). Kaiser menjelaskan dengan mengutip 2 Sam. 23:5 bahwa Daud sendiri mengenang janji yang sebelumnya ia pernah terima. Daud menamakannya "Perjanjian Kekal" (Berit 'Olani), dalam mazmurnya ia mengulangi kembali akan pernyataannya sebagai perjanjian kekal, Daud katakan "Karena Allah membuat la menjacli berkat untuk seterusny" (2000:203).

Berdasarkan penelitian diatas dapat disaksikan dalam kitab sejarah khususnya mengenai nubuatan Mesianis, tidak banyak nubuatan tersebut, kecuali yang menonjol dalam 1 Sam dan 2 Sam berikut dengan referensinya yang sejalan yaitu 1 Tawarikh. Tetapi nubuat diatas mengandung makna yang dalam seperti yang sudah dijelaskan bahwa keturunan Daud sampai kepada Kristus, Tahtanya tidak akan berakhir, melainkan abadi hal itu dinyatakan di dalam Kristus yang berkuasa di bumi dan di Surga.

\section{Kesimpulan}

Nabi-nabi sebagai pembawa pesan Allah tidak hanya menyampaikan berita kecaman dan penghukuman tetapi juga keselamatan. Berita keselamatan yang dimaksud ialah pengharapan akan Mesias yang akan datang menjadi penguasa dan Raja. Rencana keselamatan dilakukan Allah melalui seorang pemimpin atau penguasa Mesias yang dibangkitkan oleh Allah sendiri.

Para Nabi sama sekali tidak menyebutkan siapa yang akan menjadi penguasa mesianis itu akan tetapi yang pasti is seorang manusia (dalam PL masih samar-samar) yang berasal dari keluarga Daud. Keberadaan Mesias itu pun memiliki ciri yang sama dengan kepemimpinan seperti Daud. Ia seorang yang memerintah semata-mata bergantung kepada kehendak Allah dan sepenuhnya tunduk kepada kebesran dan keagungan Allah. Dalam nubuatan itu hanya berhubungan dan terkait dengan Kristus saja, karena dari segi silsilah dan referensi di PB mengemukakan bahwa yang dimaksud ialah Kristus anak Daud. 


\section{Daftar Kepustakaan}

Ensiklopedi Alkitab Masa Kini., Jakarta: OMF,. Elwell, Walter A. Analisa Topikal Terhadap Alkitab Malang SAAT, 1995

Groenen., OFM. Pengantar ke Dalam Perjanjian Lama, Yogyakarta: Kanisius, 1988.

Kaiser, Jr, Walter C. Teologi Perjanjian Lama, Malang: Gandum Mas 2000.

Ludji, Barnabas, Kerajaan Mesias, Jakarta: STT Jakarta, 1999.

McDowell, Josh. Apologetika I, Malang: Gandum Mas, 2002.

Mowvley, Harry. Penuntun ke Dalam Nubuat Perjanjian Lama, Jakarta : BPK Gunung Mulia, 2000.

Siahaan, S. M. Pengharapan Mesias Dalam PL, Jakarta: BPK Gunung Mulia, 1990.

Senduk, H.L. Kristus dalam Perjanjian Lama, Jakarta: Yayasan Bethel.

Trent, Kenneth E. Types of Christ in The Old Testament, New York: Exposition Press, 1960.

Unger's Bible Dictionary

Walvoord, John F. Yesus Kri.slus Tuhan Kita, Surabaya: Yakin. Penggenapan Nubuat Masa Kini-Zamcm Akhir, Malang: Gandum Mas, 1996. 